\title{
MENUMBUHKAN MINAT BELAJAR BAHASA INGGRIS PESERTA DIDIK SEKOLAH DASAR DI DAERAH PERBATASAN KALIMANTAN BARAT
}

\author{
${ }^{1 *}$ Winda Lidia Lumbantobing, ${ }^{2}$ Yosua Damas Sadewo \\ Institut Shanti Bhuana, Kalimantan Barat, Indonesia \\ Email : *winda.tobing@shantibhuana.ac.id
}

\author{
Manuskrip: Desember -2021; Ditinjau: Desember -2021; Diterima: Januari -2022; \\ Online: Januari-2022; Diterbitkan: Januari-2022
}

\begin{abstract}
ABSTRAK
Artikel ini merupakan hasil pengabdian masyarakat yang dilakukan sebagai perwujudan pelaksanaan Tridharma perguruan tinggi. Program pengabdian masyarakat yang dilakukan yaitu menumbuhkan minat belajar Bahasa Inggris peserta didik sekolah dasar di RT 05 Sebopet, kelurahan Sebalo, perbatasan Kalimantan-Malaysia. Kegiatan ini dilakukan dari bulan Maret sampai April, yang dilakukan 2 kali seminggu di rumah salah satu warga desa Sebopet, Kelurahan Sebalo. Terdapat 13 peserta didik sekolah dasar di RT 05 Sebopet yang terlibat. Analisis digunakan secara tematik yang dilakukan pada setiap notulensi di lapangan menunjukkan bahwa peserta didik sekolah dasar memiliki ketertarikan dalam belajar Bahasa inggris melalui nyanyian baik yang menggunakan gerakan fisik maupun tidak, permainan dan penggunaan media gambar dalam proses belajar bahasa inggris serta menggunakan aplikasi multimedia "English for Kids". Keberagaman dalam penyampaian materi dapat menarik perhatian, menimbulkan rasa keingintahuan, antusias dan semangat belajar bahasa Inggris peserta didik sekolah dasar di RT 005 Sebopet, kelurahan Sebalo, perbatasan Kalimantan Malaysia. Dapat disimpulkan program pengabdian masyarakat telah berhasil menumbuhkan minat pembelajar sekolah dasar dalam mempelajari bahasa Inggris.
\end{abstract}

\section{Kata Kunci: Minat Belajar, Bahasa Inggris, Peserta Didik}

\section{PENDAHULUAN}

Kebijakan pemerintah (SK No 060/U/1993; SK No 170/105/ 1994) tercantum bahwa Bahasa Inggris memiliki izin untuk diperkenalkan di sekolah dasar artinya bahwa sejak tahun 1993 lembaga pendidikan sudah mengetahui bahwa pentingnya untuk menguasai Bahasa Inggris. Pada umumnya, bahasa Inggris yang dikenal sebagai bahasa internasional atau bahasa asing bagi masyarakat Indonesia yang sebenarnya sangat dibutuhkan dalam kehidupan sehari-hari.

Di dalam perkembangan Ilmu pengetahuan dan teknologi (IPTEK) bahasa Inggris bukan bahasa yang harus dipahami tetapi wajib untuk dikuasi oleh semua kalangan usia, sebab dengan memiliki kemampuan bahasa Inggris yang memadai maka akan lebih mudahnya beradaptasi dalam perkembangan dunia yang semakin 
canggih, cepat, terbuka dan terkendali. Oleh karena itu, pengenalan bahasa Inggris sangat penting diterapkan kepada anak sedini mungkin baik melalui pendidikan formal maupun nonformal.

Dalam perkembangan jenjang usia manusia, pada usia 6-9 tahun, anak-anak mulai menguasai kemampuan mental dan kognitif dalam hal komunikasi baik secara lisan maupun tulisan. Maka tidak heran sebagaian besar anak sekolah dasar mempu mengoperasikan berbagai alat tehnologi seperti komputer atau ponsel yang memiliki aplikasi bahasa Inggris secara mudah (Puspitarini \& Hanif, 2019). Oleh sebab itu, anak-anak yang berada pada jenjang sekolah dasar sangat tepat diperkenalkan dan diajarkan bahasa Inggris tersebut. Menyadari pentingnya memperkenalkan Bahasa Inggris kepada anak-anak sekolah dasar. Pembelajaran Bahasa Inggris yang diterima anak-anak haruslah bermakna, artinya sumbersumber belajar, lagu-lagu berbahasa Inggris, cerita berbahasa Inggris dan kosa kata yang digunakan otentik dengan kehidupan mereka sehari-hari.

Namun pada kenyataannya, berdasarkan obsevasi awal, peserta didik pada jenjang sekolah dasar di RT 05 Sebopet masih banyak yang tidak memiliki minat dalam belajar Bahasa Inggris. Peserta didik yang berada di RT 05 Sebopet mengungkapkan bahwa tidak menyukai pelajaran Bahasa Inggris karena dianggap sulit di mana perbedaan penulisan dengan pengucapan kata-katanya dan tidak tertarik belajar Bahasa Inggris karena lebih senang berkomunikasi menggunakan Bahasa daerah dan juga bahasa Indonesia. Peserta didik tersebut juga mengungkapkan bahawa bahasa Inggris juga merupakan pembelajaran yang membosankan dan terlalu banyak yang harus dihapalkan. Di masa pandemi juga peserta didik senang bermain karena peserta didik bebas bermain kapan pun mereka inginkan terutama dalam menghabiskan waktu dengan bermain game di gawai mereka. Hal tersebut membuat orang tua mengalami berbagai tantangan dalam mendisiplinkan anak mereka. Orang tua hanya dapat menyuruh mereka belajar dan menanyakan sudah mengerjakan tugas atau belum. Namun, orang tua dan pengurus RT 05 Sebopet menginginkan adanya suatu program yang dapat mendorong anakanaknya lebih maju terutama di zaman saat ini. Orang tua mengharapkan anak dapat belajar dengan efektif meskipun di masa pandemi dan mengharapkan anak-anak mereka dapat belajar bahasa Inggris serta bisa mengaplikasikan bahasa Inggris dalam kehidupan sehari-hari. Namun, kendala yang dihadapi orang tua dan pengurus RT 05 Sebopet yaitu kurangnya sumber daya manusia yang memadai dalam mengajarkan bahasa Inggris di wilayah perbatasan. Dari wawancara yang dilakukan terhadap guru, orang tua maupun lembaga pemerintahan bahwa belum terdapat pendidikan nonformal untuk pengembangan bahasa Inggris baik dari pemerintah, swasta atau masyarakat di wilayah perbatasan. Oleh karena itu, atas keprihatinan melihat situasi tersebut, maka kami mencoba menawarkan solusi untuk mengupayakan adanya program untuk menumbuhkan minat belajar secara khusus dalam Bahasa Inggris di wilayah RT 05, Keluhan Sebalo wilayah perbatasan Kalimantan Barat - Malaysia dalam bentuk pembelajaran bahasa Inggris yang menyenangkan.

Program Mengajar di RT 05 Sebopet ini juga merupakan hasil kerjasama 
mitra Institut Shanti Bhuana Program Studi Pendidikan Guru Sekolah Dasar dengan kelurahan Bumi Sebalo Tahun 2021. Kepala Kelurahan Bumi Sebalo Ibu Erni dan bapak ketua RT 05 Sebopet dengan semangat orang tua juga untuk mengarahkan anak-anaknya mengikuti kegiatan ini dan juga bapak ketua RT 05 Sebopet menyediakan sarana dan prasarana seperti rumah beliau sebagai tempat melaksanakan kegiatan ini agar berjalan dengan baik.

Pelaksanaan kegiatan mengajar ini untuk menumbuhkan minat belajar peserta didik sekolah dasar dalam Bahasa Inggris dan diharapkan juga dapat mengubaha mind set peserta didik agar tidak menganggap bahasa Inggris sebagai pelajaran yang sulit dan membosankan. Kegiatan mengajar dilaksanakan selama 5 minggu dimulai tanggal 25 Maret 2021 sampai pada tanggal 29 April 2021 setiap hari Kamis pada pukul 16.00 WIB dan pada hari Jumat pada pukul 14.00 WIB. Pengajar dalam kegiatan mengajar ini dilakukan oleh 2 dosen yang juga mengeksplor kebutuhan peserta didik. Durasi kegiatan mengajar ini dilaksanakan 120 menit setiap pertemuan.

\section{METODE PELAKSANAAN KEGIATAN}

Adapun metode pelaksanaan kegiatan Pengabdian Kepada Masyarakat ini dilakukan dengan melalui 3 tahapan, yakni sebagai berikut:

\section{Tahap Persiapan/ Diskusi}

Mempersiapkan administrasi dalam pelaksanaan Pengabdian Kepada Masyarakat (PKM) dan juga menjadwalkan dan menentukan tempat pelaksanaan pembelajaran. Pada tahap ini juga diadakan diskusi dengan peserta didik sekolah dasar di RT 005 Desa Sebopet terlebih dahulu dengan diberikan wawasan mengenai pentingnya bahasa Inggris di era digital saat ini dan melakukan komunikasi dua arah mengenai kebutuhan peserta didik dalam belajar bahasa Inggris dan tantangan serta kendala yang mereka alami dalam belajar bahasa Inggris.

\section{Tahap Pelaksanaan/ Penerapan}

Pada tahap ini dilakukan penerapan pembelajaran bahasa Inggris yang menyenangkan yang bertujuan untuk menumbuhkan minat peserta didik dalam belajar bahasa Inggris. Pembelajaran bahasa Inggris yang menyenangkan adalah pembelajaran yang menggunakan nyanyian yang melibatkan aktivitas fisik maupun nonfisik, permainan atau games, storytelling dan penggunaan aplikasi multimedia "English for Kids" yang dapat diunduh terlebih dahulu di play store smartphone peserta didik gunakan. Pengajar akan mendidik, membimbing, memantau dan mengarahkan peserta didik selama pertemuan pembelajaran berlangsung. Pada tahap ini juga, selama melaksanakan observasi dan kegiatan mengajar berlangsung dipersiapkan notulensi kegiatan untuk menunjukkan aktivitas setiap pertemuan yang berhubungan dengan minat peserta didik sedetail mungkin.

\section{Tahap Evaluasi.}

Pada tahap ini dilakukan evaluasi untuk menemukan kekurangan dan kekuatan dari penerapan Kegiatan Pengabdian Masyarakat. Tahapan ini 
melibatkan peserta didik, orang tua dan juga kepada RT 005 Sebopet dilakukan dengan menyampaikan beberapa pertanyaan kepada mereka. Kemudian menyampaikan perkembangan peserta didik yang telah mengikuti program kegiatan Pengabdian Kepada Masyarakat berdasarkan catatan pada setiap pelaksanaan pembelajaran. Kegiatan mengajar ini dievaluasi dengan menggunakan metode observasi partisipan dengan mempersiapkan catatan lapangan yang digunakan untuk menunjukkan proses kegiatan berlangsung (Fraenkel dkk., 2011).

\section{HASIL DAN PEMBAHASAN}

Kegiatan Pengabdian Kepada Masyarakat atau yang biasa disingkat dengan PKM dilakukan sebanyak 13 kali pertemuan yang terdiri dari: 2 pertemuan di tahap persiapan yakni pada tanggal 25 Februari dan 11 Maret 2021, 10 pertemuan di tahap pelaksanaa/penerapan yakni pada tanggal 25, 16 Maret, 08, 10, 15, 16, 22, 23, 28 April 2021 dan 1 pertemuan di tahap evaluasi yakni pada tanggal 29 April 2021. Pada tahap persiapan dan diskusi dilakukan dengan durasi 60 menit dan pada tahap pelaksanaan/penerapan dan tahap evaluasi dilakukan dengan durasi 120 menit. Pada tahap pelaksanaan/ penerapan dan evaluasi pada setiap pertemuannya dilaksanakan tiga kegiatan, yaitu kegiatan pembuka, kegiatan inti dan kegiatan penutup. Notula dari lapangan observasi dan dokumentasi selama kegiatan akan digunakan untuk menjelaskan kegiatan yang dilakukan pada tiga tahapan pertemuan kegiatan pembelajaran yang dilaksanakan dalam menumbuhkan minat belajar peserta didik dalam belajar bahasa Inggris di RT 005 Sebopet.

Dalam 3 kegiatan pembelajaran pada tahap pelaksanaan/penerapan dan evaluasi dipenuhi dengan kegiatan-kegiatan yang mampu menumbuhkan minat belajar bahasa Inggris peserta didik melalui keberagaman pengajaran. Hal tersebut dilakukan tak lain agar peserta didik dapat mengenal, mengalami hingga dapat menikmati pembelajaran bahasa Inggris. Variabel yang efektif dalam mendorong peserta didik untuk belajar dan berprestasi dalam bahasa Inggris adalah minat (Harackiewicz \& Hulleman, 2010). Anak yang memiliki minat belajar memiliki perasaan tertarik dan juga senang untuk belajar, adanya partisipasi yang aktif, adanya kecenderungan untuk memperhatikan dan daya konsentrasi yang besar, memiliki perasaan positif dan kemauan belajar yang terus meningkat, adanya kenyamanan pada saat belajar, dan dimilikinya kapasitas dalam membuat keputusan berkaitan dengan proses belajar yang dijalaninya (Yunitasari \& Hanifah, 2020).

Dengan demikian selama tahap pelaksanaan/ penerapan dan evaluasi Pengadian Kepada Masyarakat ini dilaksanakan melalui pembelajaran yang menyenangkan di mana peserta didik dapat menikmati pembelajaran bahasa Inggris. Dalam penerapan setiap sesi pembelajaran juga menggunakan materi yang singkat. Dalam penyampaian materi juga dilakukan permainan seperti tebak kata, tebak bentuk gambar, mengisi teka-teki. Adapun materi yang disampaikan selama 10 pertemuan yakni:

1. Introduce yourself 
2. Alphabet

3. The part of body

4. Colours

5. Shapes

6. Animals

Dari materi yang singkat dan tidak terlalu mendalam ini peserta didik dituntun untuk lebih mengaplikasikannya secara lisan dan tulisan. Berikut salah satu dokumentasi dalam penyampaian materi pembelajaran.

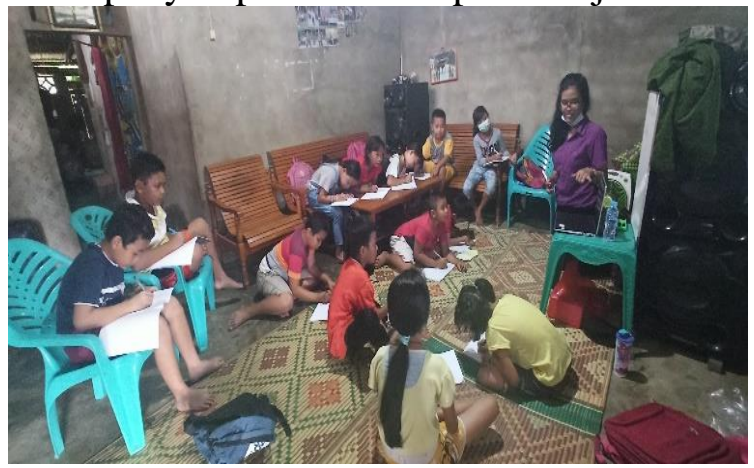

Gambar 1. Pemberian materi ajar bahasa Inggris

Setiap pembukaan dan penutupan pembelajaran juga diadakan bernyanyi bersama agar pembelajaran lebih menarik perhatian peserta didik dan tidak merasa bosan. Berikut beberapa lagu dan liriknya yang dipelajari peserta didik.

Head, Shoulders, Knees and Toes,

Head, Shoulders, Knees and Toes,

Knees and Toes

Head, Shoulders, Knees and Toes,

Knees and Toes

(Cited in www.scoutsong.com)

C-O-C-O-N-U-T

N-U-T, N-U-T

C-O-C-O-N-U-T

N-U-T, N-U-T

Coconut

(Cite in YouTube)

Hello!

Every day

I go to school

I meet my friends

and we all say

hello..hello

how are you?

I'm good 
I'm great

How about you?

Na na na na na na na na na na

na na na na na

(Cite in www.supersimple.com)

Lagu-lagu anak ini yang dipakai dalam aktivitas pembukaan dan penutupan pembelajaran bahasa Inggris. Hal ini dilaksanakan untuk mempermudah peserta didik mengenal alphabet, bagian-bagian tubuh dan kalimat bahasa Inggris yang sering mereka lakukan setiap hari. Kemudian dalam beberapa pertemuan pembelajaran, peserta didik juga menonton cerita singkat seperti "red shoes". Dengan demikian peserta didik merasa bahagia dalam belajar bahasa Inggris. Berikut salah satu dokumentasi dalam kegiatan bernyanyi peserta didik.

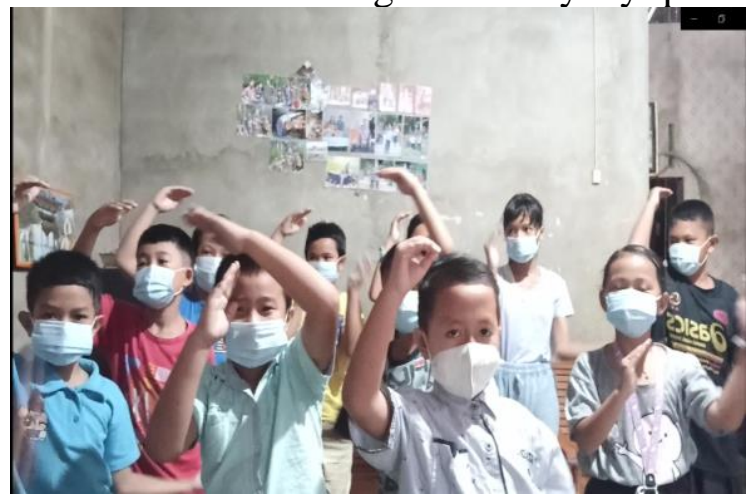

Gambar 2. Kegiatan bernyanyi bersama

Berbagai macam lagu yang diterapkan pada peserta didik disesuaikan dengan tingkat kemampuan mereka. Kegiatan bernyanyi seperti yang dilakukan tidak hanya mengembangkan kognitif peserta didik, tetapi juga mengembangkan psikomotorik anak misalnya seperti lagu Head, Shoulder, Knees and Toes dan coconut. Ketika dalam kegiatan bernyanyi juga, peserta didik diajak bermain seperti di mana peserta didik harus menunjukan bagian tubuh yang diucapkan oleh pengajar, bukan mengikuti apa yang disentuh oleh pengajar. Dengan demikian melalui permainan atau games juga peserta didik semakin memberi perhatian pada apa yang sedang dipelajari. Hal tersebut juga dikemukakan Budiarta \& Kasni, 2020) bahwa game yang digunakan harus berkaitan dengan topik yang sedang didiskusikan dan topik itu mampu melibatkan siswa dalam proses pembelajaran tersebut. Kegiatan permainan yang mengembangkan aktivitas psikomotorik seperti hal tersebut tidak hanya membantu peserta didik belajar bahasa Inggris dengan cara menggerakkan badan mereka namun juga membangun minat mereka belajar bahasa Inggris (Lindt \& Miller, 2018; Snyder dkk., 2017).

Dalam pelaksanaan Pengabdian Kepada Masyarakat ini juga menerapkan pembelajaran menggunakan aplikasi multimedia interaktif "English For Kids". Hal ini dilakukan berdasarkan hasil observasi di mana peserta didik sering menggunakan gawai atau smartphone di masa pandemi yang mengharuskan belajar 
dari rumah. Peserta didik menggunakan gawai tidak hanya untuk mengerjakan tugas yang dikirimkan guru, tetapi menggunakan gawai mereka untuk bermain game online yang tidak ada kaitannya dengan pembelajaran. Oleh sebab itu, peserta didik dikenalkan dengan aplikasi multimedia interaktif seperti "English for Kids" tersebut. Para pengajar membimbing peserta didik selama pengenalan dan pengperasian aplikasi tersebut. Berikut salah satu dokumentasi pengperasian aplikasi "English For Kids" di gawai peserta didik.

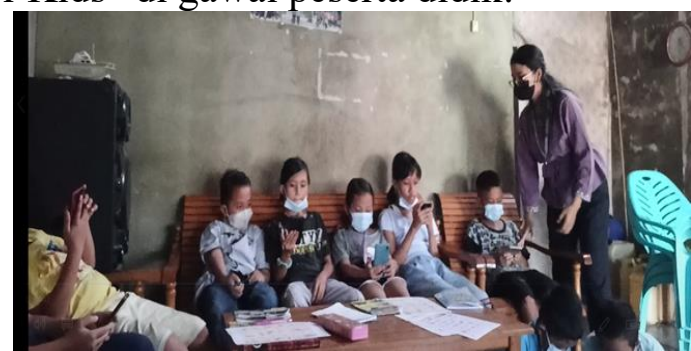

Gambar 3. Pengoperasian aplikasi "English For Kids" di gawai peserta didik.

Dengan adanya media pembelajaran berbasis multimedia interaktif ini, maka proses pembelajaran semakin lebih bervariasi dibandingkan sebelumnya. Kemudian juga orang tua pun bisa mengajari anak dengan menggunakan media tersebut dalam proses pembelajaran yang memudahkan anak untuk lebih paham materi bahasa Inggris dan juga mengoptimal dalam proses penumbuhan minat belajar bahasa Inggris.

\section{KESIMPULAN}

Pembelajaran bahasa Inggris menggunakan berbagai macam penyampaian pengajaran terutama menggunakan teknologi yang berkembang di era digital saat ini dalam menumbuhkan minat peserta didik dalam belajar bahasa Inggris memberikan pengaruh yang positif terutama pada masa pandemi ini di mana anakanak sering sekali menghabiskan waktu dengan bermain gawai dalam belajar. Peserta didik sekolah dasar yang berada dalam RT 005 Sebopet Kelurahan Sebalo wilayah perbatasan Kalimantan Barat - Malaysia menunjukkan sikap antusias, senang dan bersemangat ketika belajar bahasa Inggris sebagai wujud nyata keberhasilan pelaksaan program ini. Peserta didik yang sangat berharap program ini terus berlangsung secara terus menerus menjadi pertimbangan yang sangat baik lagi untuk meneruskan program ini untuk semakin mendukung peserta didik mencapai kemampuan berbahasa Inggris yang lebih optimal lagi.

\section{DAFTAR PUSTAKA}

Budiarta, I. W., \& Kasni, N. W. (2020). Menumbuhkan Minat Belajar Bahasa Inggris Siswa Sekolah Dasar Melalui Metode 'Esa'. Linguistic Community Service Journal |, 1(1), 23-34.

Murayama, K., FitzGibbon, L., \& Sakaki, M. (2019). Process account of curiosity and interest: A reward-learning perspective. Educational Psychology Review, $31(4), 875-895$. 
Nurjaya, N., et al. (2020). Edupreneurship management in shaping the nation's character. Jurnal Konseling dan Pendidikan, 8(3), 198-206.

Harackiewicz, J. M., \& Hulleman, C. S. (2010). The importance of interest: The role of achievement goals and task values in promoting the development of interest. Social and Personality Psychology Compass, 4(1), 42-52.

Haryadi, R. N. (2020). Pengaruh Pengaruh Kebiasaan Membaca Terhadap Kemampuan Berbicara Bahasa InggriS SMA Negeri 99 Jakarta. Jurnal Manajemen Bisnis dan Keuangan, 1(2), 14-30.

Hasan, A., Othman, Z., \& Mohd Majzub, R. (2015). Using active, creative, effective and joyful (ACEJ) learning strategies toward English achievement and their behavioural changes among primary school students. Mediterranean Journal of Social Sciences, 6(6).

Lindt, S. F., \& Miller, S. C. (2018, Agustus 24). Movement and learning in elementary school. Phi Delta Kappan. https://kappanonline.org/lindt-miller movement-learning-elementary-school-physical-activity

Puspitarini, Y. D., \& Hanif, M. (2019). Using Learning Media to Increase Learning Motivation in Elementary School. 4(2), 53-60.

Yunitasari, R., \& Hanifah, U. (2020). Pengaruh Pembelajaran Daring terhadap Minat Belajar Siswa pada Masa COVID 19. Edukatif: Jurnal Ilmu Pendidikan, 2(3), 232-243. https://doi.org/10.31004/edukatif.v2i3.142

https://www.scoutsongs.com/lyrics/headshoulders.html

https://supersimple.com/song/hello/ 